\title{
Chapter 16 \\ Unraveling the Complexity of Tourist Experience with NFC Technology and Mobile Wallets
}

\author{
Federica Palumbo and Gandolfo Dominici
}

\begin{abstract}
By considering the tourist experience as a complex dynamic system, in this paper we depict the traveler as a kybernetes ( word for 'sea captain', 'steersman', or 'governor') in search of powerful tools to help him or her to obtain directions in the mare magnum of complexity, overcoming the fear of action and taking decisions. We focus our attention on the key role of Near Field Communication technology and mobile wallet as 'attenuators of complexity' in the travel and tourism industry.
\end{abstract}

Keywords Smart • Complexity - Simplexity • Mobile technology • NFC technology $\cdot$ Mobile wallet $\cdot$ Tourist satisfaction

Everything is simpler than you think, and at the same time, more complex than you imagine.

Johann Wolfgang von Goethe

\subsection{The Smart Revolution in Tourist Experience: From Complexity to Simplexity}

The European Union (EU), in its Europe 2020 strategy, has emphasized the need to sustain a 'smart, sustainable and inclusive growth' that might emerge stronger from the economic and financial crisis of the coming years (COM 2010). With the aim of simplifying complexity in the life of citizens, the scientific community is dealing

\footnotetext{
F. Palumbo $(\square)$

Department of Management, Sapienza University of Rome, Via del Castro Laurenziano, 9, 00161 Rome, Italy

e-mail: federica.palumbo@uniroma1.it

G. Dominici

Business Systems Laboratory, Via Circumvallazione, 77, 83100 Avellino, Italy

e-mail: gandolfo.dominici@libero.it 
with the development of new models of 'Smart Cities', based on ICT, sustainable growth, social inclusion, and the quality of life in urban areas.

What does the term 'smart' exactly mean?

The concept of 'smart' can be summarized with the phrase 'the complexity of simplicity'. Indeed, the main new challenge of the smart era is to provide complex products or services that can be perceived as simple, useful, and time-saving by users.

Creating new technologies to simplify complexity is, in itself, rather complex, but is necessary for action. Berthoz (2012) proposed the neologism 'simplexity' to describe the simplifying principles that make it possible to process complex situations very rapidly, elegantly, and efficiently, taking past experience into account and anticipating the future.

This 'smart revolution' should not overlook the tourism industry. Tourists need to deal with a high level of complexity in their travel decisions, and so turning complexity into simplicity is particularly valuable in this industry.

The tourism sector has been described as highly information-intensive (Poon 1993), and involves a wide variety of different processes (Egger 2013). The onset of mass travel and tourism has seen the pain of delays, lost luggage, and seemingly ever-increasing queues confront many travelers. In addition, we can see how the industry is often fragmented and lacking a kybernetes able to manage it (Dominici 2013). For the consumers of tourist services, the effect of this fragmentation is that they are swamped with information from different sources; they need to spend a great deal of time and energy to make decisions and act.

We argue with that stream of tourism literature that suggests that travel is a 'linear process', consisting of three different temporal phases (anticipatory, experiential, and reflective) (Craig-Smith and French 1994; Graburn 1989; Jennings 1997, 2006), and we embrace the view of the tourism industry as a dynamic complex system, presenting emergent variables and nonlinear evolutionary paths (Baggio 2013; Faulkner 2001; Faulkner and Russell 1997, 2001; Faulkner and Vikulov 2001; Russell and Faulkner 1999, 2004; Zahra and Ryan 2007). In such circumstances, there is the need for a criterion to select those factors that are relevant to managing the complexity of tourist experience. Espejo and Rayes (2011: 54) called this criterion the 'attenuator of complexity', defining it as "any device, mechanism or procedure reducing the number of states in a [complex] situation".

Thus, new technologies, designed to simplify complexity, can bring tremendous advantages to the tourism industry. A new model of 'Smart Tourism' should emerge as an innovative view of tourism supported by the new digital (and in particular, mobile) technologies, and oriented towards improving and simplifying the tourist experience.

Considering mobile phones as powerful mediators of the tourist experience, we describe in this paper two attenuators of complexity that can be incorporated into mobile devices: NFC technology and mobile wallet. 


\title{
16.2 Mobile Tourism
}

Today, we carry our smartphones everywhere we go, using them for communication, mapping, and many other applications that make our lives easier. Mobile and wireless technology incorporated into smartphones and other mobile devices has an increasing impact on everyday life. Smart phones and mobile devices can play a key role in mediating the tourist experience (Wang et al. 2012a), because tourists use mobile technology before, during, and after the travel.

Smart phones and mobile devices can help travelers' decision-making process by providing easy access to information anywhere and at any time, and by enabling travelers to learn about new travel opportunities and to become more familiar with a destination (Brown and Chalmers 2003; O’Brien and Burmeister 2003; Rasinger et al. 2007).

\begin{abstract}
Imagine a traveler driving on an Interstate highway in America. With the assistance of a GPS-enabled iPhone, he/she accesses Google Map for driving directions. Rock music is played through the car's stereo system with the streaming music coming from the Spotify app on the phone. With a little help from the embedded search engine, he/she locates a restaurant of one of his favorite brands 20 miles away along the highway; and, fifteen minutes later arrives at the restaurant and instantly checks in through the Four-square app equipped with the location-awareness capabilities. His/her status is immediately updated so that he/she can now interact with friends through various social networks, such as Facebook and Twitter. Wang et al. 2012b: 309)
\end{abstract}

According to several authors (Ricci 2011; Buhalis and Law 2008; Wang et al. 2012a; Palumbo et al. 2013), smart phones and other mobile devices are becoming the most promising area for promoting technological innovation in the tourism sector.

\subsection{Near Field Communication Technology}

Near Field Communication (NFC) has been defined as a proximity technology (up to $5 \mathrm{~cm}$ at a speed of $400 \mathrm{kB} / \mathrm{sec}$ ) for data transfer without physical touch, which has evolved from Radio Frequency Identification (RFID) (Ok et al. 2010; Pesonen and Horster 2012). NFC allows people to interact with objects through the help of a smart phone or other mobile device, revolutionizing daily habits.

According to the International Air Transport Association (IATA 2009), NFC is the third wave in the mobile telephony revolution, after mobile voice and text and mobile internet communication (Egger 2013).

NFC technology traces its roots to a joint venture between Sony and Philips (Sony 2002). Its development was then promoted by the NFC Forum, a collaboration established between these two firms and Nokia. 
NFC technology can operate in three modalities (Ok et al. 2010):

- Peer-to-peer: data is transferred between two NFC-compatible devices.

- Reader/Writer: data is transferred between NFC tag and mobile devices.

- Card emulation: data is transferred from mobile devices to NFC reader.

The main advantage of NFC technology is its dematerialization', meaning that all the information normally included in physical devices (badges, credit cards, access keys, etc.) is stored inside the smart phone.

Other advantages of this technology include the speed of exchange of information (useful, for example, for cash spending or transport) and the convergence of the offline and the online world (by making available more information about the products in a physical store).

Tourism is a promising area for developing this technology. Pesonen and Horster (2012: 11) have stated that "NFC has been predicted to be one of the next big things in technological progress and it can potentially have a huge effect on both the tourism business and tourism research". Some applications of NFC technology in the tourism industry already exist. Nevertheless, this technology is relatively recent, and its potential is still underexploited.

\subsection{The Mobile Wallet}

The mobile wallet, or multi-wallet, is a type of application for smart phones that integrates a physical wallet, money, payment cards, keys, and other cards, enabling users to simultaneously use all these cards using only a smart phones equipped with Near Field Communication technology.

A mobile wallet can be used for different purposes: mobile payment, mobile ticketing, vouchers and couponing, digital identity, loyalty cards, and customized and geolocalized offers.

According to Fischer (2009), an electronic wallet could replace credit, debit, transportation, access, and loyalty cards, and it could also be used for vending machines.

NFC technology, enabling smart phones and other mobile devices to become mobile wallets, will simplify and considerably improve customer experience.

Payment companies are investing heavily to determine the best ways to implement mobile payment, which would allow their users to pay for everyday goods by phone. They expect that this payment system will eventually be available in every store, and that this technology will be on every phone across the world, making credit cards extinct. 


\subsection{NFC Technology and Mobile Wallet in Tourist Experience}

According to Madlmayr and Scharinger (2010) NFC technology and mobile wallets may be useful for a number of tourist purposes: access authorization, loyalty programs, mobile payment, Bluetooth and Wi-Fi configuration, VCard transfer, Smart Poster, data exchange, OTA (over-the-air) provisioning, ticket upload, and money top-up (i.e. preloading money).

Kneißl et al. (2009) affirm that NFC technology may be useful, not only for payments and ticketing, but also for social purposes in the tourism industry. For example, allowing users to share places they have visited on social networks by simply bringing the NFC device near to in-location tags. Ok et al. (2010) have imagined NFC-based services in hotels, for example, as automated check-in systems.

Ho and Chen (2011) studied the impact of NFC technology on user satisfaction. They hypothesized that restaurants could customize menus and offer special discounts to guests equipped with NFC enabled devices, improving their experience and enhancing their satisfaction.

Fischer stated that "The customer sees an advertisement, likes what he/she sees, waves the phone, and orders the product right there. Imagine arriving at an airport, going to a hotel advertisement board, choosing a hotel that looks good, and waving the phone reader over the tag; the phone either offers the URL to go to the reservations Webpage or just dials the number, and stores the address in your phone. You confirm with the hotel. You then go to your rental car and wave the phone over the navigation system for a peer-to-peer connection; the address you got from the board is transferred into the navigation system, and you are on your way." (2009: 24).

\subsection{Conclusions}

The next decade and beyond will see a qualitative shift in the travel and tourism experience. Our research suggests that an era of 'smart tourism' will soon emerge and transform how people experience travel.

NFC technology and mobile wallets hold great promise for tourism marketing and advertisement. Through mobile-based promotion, they can become increasingly popular tools (Okazaki and Hirose 2009) and might contribute to the diffusion of mobile coupons and customized discounts (Pesonen and Horster 2012).

In this work, we have presented a first conceptual effort which, far from being exhaustive, may serve to stimulate further reflection on the benefits of NFC technology and mobile wallet in unraveling the complexity of the tourist experience.

This research is the first step in a wider research program that aims to design new tourist services based on NFC technology and mobile wallets, in line with the drivers of tourist satisfaction. In the further steps of this research, we intend to apply 
the model proposed by Kano et al. (1984), in which customer needs are identified and transformed into design requirements, engineering specifications, and production details (Dominici and Palumbo 2013a, b).

We are fully aware that this work is not without limitations. In particular:

- NFC technology and mobile technology are still not widely known to users.

- The tourism sector is highly fragmented and is characterized by the existence of many small companies that often lack sufficient resources to invest in new technologies and infrastructure.

- Local authorities have few financial resources to invest in improving tourist offerings.

In the future, we aim to interview tourists so as to evaluate their familiarity with and acceptance of NFC technology and mobile wallets. We aim also to interview local authorities and travel, leisure, and hospitality companies, in order to test their interest (or lack thereof) in developing a range of new services based on NFC and mobile wallets.

\section{References}

Baggio R (2013). Studying complex tourism systems: a novel approach based on networks derived from a time series. In: Proceedings of XIV April international academic conference on economic and social development, Moscow, 2-5 Apr 2013

Berthoz A (2012). Simplexity: simplifying principles for a complex world. Yale University Press, New Haven

Brown B, Chalmers M (2003) Tourism and mobile technology. In: Proceedings of the eighth conference on European conference on computer supported cooperative work. Kluwer Academic, Helsinki, (Finland), pp 335-354

Buhalis D, Law R (2008) Progress in information technology and tourism management: 20 years on and 10 years after the internet - the state of eTourism research. Tourism Manage 29 (4):609-623

COM (2010) Europe 2020: a strategy for smart, sustainable and inclusive growth. Communication from the Commission. http://ec.europa.eu/eu2020/pdf/COMPLET\%20EN\%20BARRO SO\% $20 \% 20 \% 20007 \% 20-\% 20$ Europe $\% 202020 \% 20-\% 20$ EN\%20version.pdf

Craig-Smith S, French C (1994) Learning to live with tourism. Pitman, Melbourne (Australia)

Dominici G, Palumbo F (2013a). The drivers of customer satisfaction in the hospitality industry. Applying the Kano's Model to Sicilian Hotels. Int J Leisure Tourism Mark 3(3):215-236

Dominici G, Palumbo F (2013b) How to build an e-learning product: factors for student/customer satisfaction. Bus Horiz 56(1):87-96

Dominici G (2013) Complexity and action: reflections on decision making and cybernetics. Bus Syst Rev 2(2):38-47

Egger R (2013) The impact of near field communication on tourism. J Hospitality Tourism Technol 4(2):2013

Espejo R, Reyes A (2011) Organizational systems. Springer, Heidelberg

Faulkner B (2001) Towards a framework for tourism disaster management. Tourism Manage 22 (2):135-147

Faulkner B, Russell R (1997) Chaos and complexity in tourism: in search of a new perspective. Pac Tourism Rev 1:93-102 
Faulkner B, Russell R (2001) Turbulence, chaos and complexity in tourism systems: a research direction for the new millennium. In: Faulkner B, Moscardo G, Laws E (eds) Tourism in the 21st century: lessons from experience. Continuum, London, pp 328-349

Faulkner B, Vikulov S (2001) Katherine washed out one day, back on track the next: a postmortem of a tourism disaster. Tourism Manage 22(4):331-344

Fischer J (2009) NFC in cell phones: the new paradigm for an interactive world. IEEE Commun Mag 47(6):22-28

Graburn N (1989) Tourism: the sacred journey. In: Smith V (ed) Hosts and guests: the anthropology of tourism. University of Pennsylvania, Philadelphia, pp 21-36

Ho T, Chen R (2011) Leveraging NFC and LBS technologies to improve user experiences. In: 2011 International joint conference on service sciences, IEEE, Taipei (Taiwan), 25-27 May 2011, pp 17-21

IATA (2009) Airline passengers call for more self-service. www.iata.org/pressroom/pr /Pages/ 2007-20-11-01.aspx

Jennings GR (1997) The travel experience of cruisers. In: Oppermann M (ed) Pacific Rim 2000: issues, interrelations, inhibitors. CAB International, London, pp 94-105

Jennings GR (2006) Perceptions on quality tourism experience. In: Jennings G, Nickerson NP (eds) Quality tourism experiences. Elsevier Butterworth-Heinemann, Oxford, pp 1-22

Kano N, Seraku N, Takahashi F, Tsuji S (1984) Attractive quality and must-be quality. Hinshitsu J Japan Soc Qual Control 14(2):39-48

Kneißl F, Röttger R, Sandner U, Leimeister JM, Krcmar H (2009) All-I-Touch as combination of NFC and lifestyle. In: Proceedings of the 1st international workshop on near field communication. IEEE, Hagenberg (Austria), 24-26 Feb 2009, pp 51-55

Madlmayr G, Scharinger J (2010) Neue Dimensionen von mobilen Tourismusanwendungen durch Near Field Communication Technologie. In: Egger R, Jooss M (eds) mTourism. Mobile Dienste im Tourismus, Gabler Verlag, Wiesbaden (Germany), pp 75-88

O'Brien P, Burmeister J (2003) Ubiquitous travel service delivery. Inf Technol Tourism 5 (4):221-233

Ok K, Coskun V, Aydin M, Ozdenizci B (2010) Current benefits and future directions of NFC services. International Conference on Education and Management Technology (ICEMT). IEEE, Cairo (Egypt), 2-4 Nov 2010, pp 334-338

Okazaki S, Hirose M (2009) Does gender affect media choice in travel information search? On the use of mobile Internet. Tourism Manage 30(6):794-804

Palumbo F, Dominici G, Basile G (2013) Designing a mobile app for museums according to the drivers of visitor satisfaction. In: Raguz IV, Roushdy M, Salem ABM (eds) Recent advances in business management and marketing. WSEAS Press, USA, pp 159-166

Pesonen J, Horster E (2012) Near field communication technology in tourism. Tourism Manage Perspect 4:11-18

Poon A (1993) Tourism, Technology and Competitive Strategies. CAB International, Oxford

Rasinger J, Fuchs M, Hopken W (2007) Information search with mobile tourist guides: a survey of usage intention. Inf Technol Tourism 9(3-4):177-194

Ricci F (2011) Mobile recommender systems. Inf Technol Tourism 12(3):205-231

Russell R, Faulkner B (1999) Movers and shakers: chaos makers in tourism development. Tour Manag 20(4):411-423

Russell R, Faulkner B (2004) Entrepreneurship, chaos and the tourism area lifecycle. Annals of Tourism Research 31(3):556-579

Sony (2002) Philips and Sony announce strategic cooperation to define next generation near field radio-frequency communications. http://www.sony.net/SonyInfo/News/Press_Archive/ 200209/02-0905E/

Wang D, Park S, Fesenmaier D (2012a) The role of smartphones in mediating the touristic experience. J Travel Res 51(4):371-387 
Wang D, Xiang Z, Fuchs M, Ricci F, Cantoni L (2012b) The new landscape of travel: a comprehensive analysis of smartphone apps. In: Information and communication technologies in tourism 2012, Helsingborg (Sweden), 25-27 Jan 2012. http://www.cabdirect.org /abstracts/ 20123059 850.html

Zahra A, Ryan C (2007) From chaos to cohesion-Complexity in tourism structures: an analysis of New Zealand's regional tourism organizations. Tourism Manage 28:854-862 